\title{
On farm demonstrations on response of chickpea to irrigation in farmers fields of Anantapuram district of Andhra Pradesh
}

\author{
C. RADHA KUMARI* P. LAKSHMI REDDY ${ }^{1}$ AND M. JOHN SUDHEER \\ District Agricultural Advisory and Transfer of Technology Centre, ANANTAPURAM (A.P.) INDIA \\ (Email : radhaphd@yahoo.in)
}

\begin{abstract}
Six on-farm demonstrations were conducted to popularize the effect of irrigation on growth, yield components, yield and economics of chickpea in two villages viz., Akuledu and R. Kothuru of Anantapuram district with an area of 7.2 hectares during Rabi season over a period of 3 years from 2007-08 to 2009-10. The results revealed that growth parameters like plant height, number of pods per plant, hundred pod weight, hundred seed weight of chickpea were improved by providing irrigation at 35 and 55 DAS compared to farmers practice. By giving irrigation at 35 and 55 DAS plant height, number of pods per plant, 100 pod weight and 100 seed weight were increased by $9.1,38.7,16.9$, and 23.4 per cent, respectively over farmers practice. Irrigation at 35 and 55 DAS recorded higher seed yield (2006 kg ha-1) which was 35.1 per cent higher over farmers practice $\left(1485 \mathrm{~kg} \mathrm{ha}^{-1}\right)$. Gross returns (Rs. 44655/-) and net returns (Rs. 34080/-) per hectare were more with irrigation at 35 and 55 DAS compared to farmers practice (Rs. 32783/- gross returns and Rs. 19908/- net returns).
\end{abstract}

Key Words : Chickpea, Irrigation, Farmers fields, Anantapuram district

View Point Article : Kumari, C. Radha, Reddy, P. Lakshmi and Sudheer, M. John (2015). On farm demonstrations on response of chickpea to irrigation in farmers fields of Anantapuram district of Andhra Pradesh. Internat. J. agric. Sci., 11 (2) : 337-340.

Article History : Received : 11.04.2015; Accepted : 20.05.2015

\footnotetext{
* Author for correspondence (Present Address) : Agricultural Research Station, ANANTAPURAM (A.P.) INDIA ${ }^{1}$ Krishi Vigyan Kendra, ANANTAPURAM (A.P.) INDIA
} 